\title{
Assessment of the groundwater suitability for irrigation near Al Kufa City and preparing the final water quality maps using spatial distribution tools
}

\author{
Ali A. Al Maliki ${ }^{1}$ Zainab D. Abbass ${ }^{2}$ - Hussain M. Hussain ${ }^{3,4} \cdot$ Nadhir Al-Ansari $^{5}$ (D)
}

Received: 25 July 2019 / Accepted: 15 June 2020 / Published online: 28 June 2020

(c) The Author(s) 2020

\begin{abstract}
In many parts of the world, groundwater quality is decreasing due to urbanization industrialization and use of agricultures in rural areas. This subject has formed an urgent need to determine the suitability of groundwater for various purposes. The aim of this study is to determine a groundwater index for groundwater use for irrigation in agriculture. The study is carried out in an agricultural area; near Al Kufa city, North of Al Najaf province, Iraq. Many chemical variables are used in this model, including (total dissolved solids TDS, electrical conductivity EC, sodium Na, potassium $\mathrm{K}$ and iron $\mathrm{Fe}$ ), in addition to some of the heavy metals (cadmium $\mathrm{Cd}$, lead $\mathrm{Pb}$, chromium $\mathrm{Cr}$, and nickel $\mathrm{Ni}$ ), that also added to the index. The weight's parameters are determined using analytical hierarchy process (AHP) and classified into five groups based on the human health significance of these parameters and negative effect on agriculture. The result of this study indicates that the water quality index (WQI) records values between ( 0 and 4.33), and in which the value of (2.16) represents the limit between unpolluted and polluted groundwater. This study confirms that all groundwater samples over the study area are suitable for agriculture. The final WQI values are exported to ArcMap environment to prepare the final WQI maps of study area.
\end{abstract}

Keywords Groundwater $\cdot$ Water quality $\cdot$ Spatial analysis $\cdot$ Water pollution

\section{Introduction}

Nadhir Al-Ansari

nadhir.alansari@1tu.se

Ali A. Al Maliki

alyay004@mymail.unisa.edu.au

Zainab D. Abbass

zainabd.abbas@uokufa.edu.iq

Hussain M. Hussain

hussainm.alshimmary@uokufa.edu.iq

1 Environment Research Centre, Ministry of Science and Technology, Jadriah, Baghdad, Iraq

2 Faculty of Physical Planning, University of Kufa, Najaf, Iraq

3 Remote Sensing Center, University of Kufa, Najaf, Iraq

4 Department of Geology, Faculty of Science, University of Kufa, Najaf, Iraq

5 Department of Civil, Environmental and Natural Resources Engineering, Lulea University of Technology, Lulea, 97187 Lulea, Sweden
The deficiency of fresh resources has become a critical apprehension worldwide. Physical and chemical parameters play significant characteristics in assessing the water quality. However, studying these parameters on an individual basis doesn't clearly outline water quality (Orozco et al. 2017). In any case, the parameters must meet pre-established standards for water use in a particular region or country, otherwise, treatment before use is required if the water does not meet the standards (Orozco et al. 2017). Geochemical studies of groundwater provide a better understanding of possible changes in quality (Bouderbala 2017). Such studies integrate a set of physical and chemical variables to develop a WQI, where a single number which represents the level of water quality, derives from a large number of water parameters (Patrick and William 2013). This process makes the results more easily and rapidly understood for decision makers to evaluate the quality and potential risk of a given water body, based on various parameters (Tyagi et al. 2013). It also assists in holding the comparison between various sampling sites and/or events (Alobaidy et al. 2010). The quality 
of the irrigation water has to be evaluated to avoid or, at least, to minimize negative impacts on agriculture (Hussain et al. 2014). WQI is considered a numerical or mathematical method that gives the public a general idea for the quality of groundwater in the arid and semi-arid regions (Alobaidy et al. 2010; Ramakrishnaiah et al. 2009). Using the WQI methodology makes of reduce the cost and time necessary to drill the wells for agriculture purposes within the area of high pollution in groundwater, so that delineate the good areas of groundwater to expand the human populations and establish others in the areas non inhabited, in addition to limit the polluted areas for healthy embedding. Attempts to develop water related indicators are not new. Since early 1960s, efforts have been underway to develop a meaningful set of indicators and indices for water resources. The evaluation of water quality is related to soil problems, which is interrelated to salinity, toxicity, water infiltration rate, and other miscellaneous problems. The groundwater quality refers to the characteristics of a water source, which will influence its suitability for a specific use. Consequently, the number of physic al and chemical parameters which define the groundwater qualities that are to be monitored for proper assessment of groundwater quality (Hussain et al. 2012). Initially, the general WQI has been developed by Brown et al. (1970) which were based on weights to individual parameter (Brown et al. 1970). McClelland (1974) applied the geometric mean form of weighting to the WQI. McClelland was concerned that the arithmetic mean less sensitivity to low variable value (McClelland 1974). Recently, many modifications were considered for WQI model through various researchers and experts (Tyagi et al. 2013; Gautam et al. 2013; Tiwari 2014; Thakur et al. 2015; Rawat et al. 2017). The present study applied the index of aquifer water quality suggested by (Melloul and Collin 1998), which it was initially used the chloride $(\mathrm{Cl})$ and nitrate $\left(\mathrm{NO}_{3}\right)$ for assessing the groundwater vulnerability to potential pollution. However, the index map did not adequately address the implicit pollution of ground water for agriculture purpose by taking only two parameters. Therefore, the modifications were made in the original framework of Melloul and Collin index and their procedure was developed to involve the weights assigned and their relative importance parameters as per their analytical hierarchy in violating the (irrigation water) standards and not as an arbitrary means (as taken by Melloul and Collin). The WQIs were integrated using the geographical information system (GIS) to generate variability thematic maps through ArcGIS software. The WQI and GIS showed a great potential in the assessment of water for multi-purpose usage. The WQI and GIS are excellent tools for summarizing overall water quality conditions over space and time. When used together, they are also a method of providing relevant information for specific water use that can be more readable for planners and managers. The objective of the present work is to assess the groundwater quality for irrigation usage based on computed WQI and to prepare the final WQI maps using GIS spatial distribution tools.

\section{The hydrogeology of the study area}

The study area represents a rural region for Al Najaf province, about $170 \mathrm{~km}$ south of Baghdad. The geological formation of study area (Dibdibba formation) is composed from sequences of clay stone, siltstone, sandstone with silt layers of chalky limestone (Al Azawi 2009). Study area is located in the west of Euphrates River $\left(32^{\circ} 10^{\prime}-32^{\circ} 40^{\prime}\right.$ North latitude and $44^{\circ} 21^{\prime}-44^{\circ} 25^{\prime}$ East longitude) with a total area of $\sim 22.6 \mathrm{~km}^{2}$. The study area is initially selected using the satellite image in the map grid of Iraq and displayed using ArcMap 10.5 on GIS environment (Fig. 1). In the area of study, Shatt Al-Kufa (Kufa River) is the major supply of water needed for drinking, irrigation, industry and other applications. This river shows decreasing quantity and quality of water because of the rapid growth of industrial, agricultural and municipal activities. Groundwater is another important source of water in this area especially for irrigation. In the last few years, farmers started to dig wells in many areas to use them for agriculture; many vegetables are now produced in considerable amount by using groundwater. The groundwater flow is affected for Al Dibdibba aquifer, mainly by the permeability and high density of horizontal fractures in rock, which are in touch with the groundwater and by the hydraulic gradient (Al Azawi 2009).

The study area represents the extreme eastern part of $\mathrm{Al}$ Dibdibba aquifer, which is one of the most important aquifers in Iraqi western desert area. This region is characterized by its lack of surface water and low annual rainfall, which does not exceed $100 \mathrm{~mm}$ per year (Al-Ansari 2013). In addition, the potential rate of evaporation in the desert is several times greater than the average rainfall. Many studies conclude that the source of most of Dibdibba water comes from an old period that associated with or followed by the deposition Dibdibba aquifer while the direction of the groundwater flow is from southwest to the north east of the study area (Al-Kubaisi et al. 2018).

\section{Methodology}

\section{Sampling and physiochemical parameters}

Twelve sites with triplicate groundwater samples from each site were collected from different wells distributed all over the study area during 2016 (Fig. 1). Sample size is calculated using the random sampling method under global conditions mentioned in (USEPA 2002), this method is easy to 


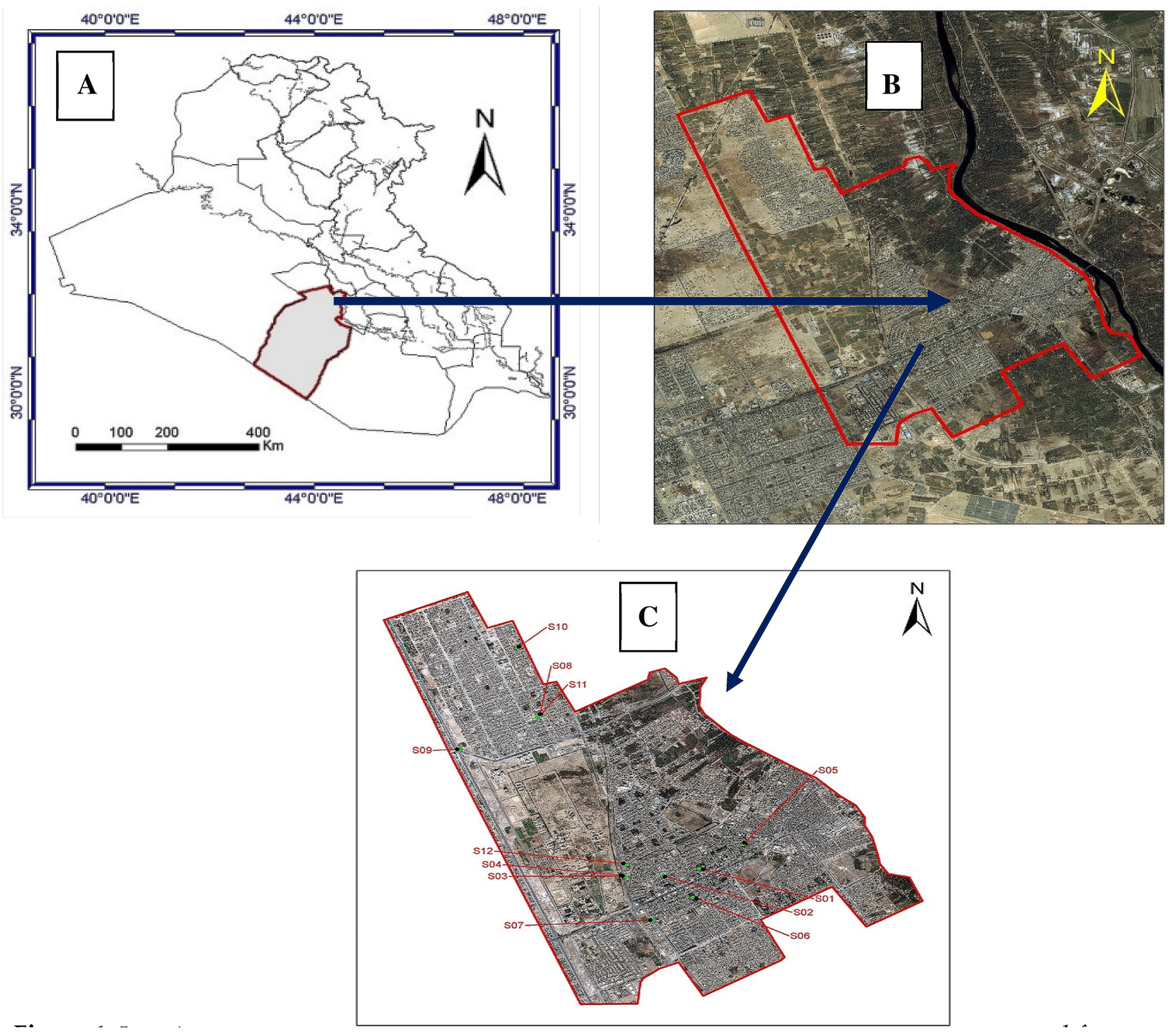

Fig. 1 Location map of the study area with sampling sites. a Iraq map. b Study area extracted from satellite image. c Sampling sites

understand, and the equations for determining sample size are relatively straightforward. Random sampling method was chosen her due to the aquifer in the area of study is relatively homogeneous and no major patterns of contamination or "hot spots" are expected U.S. Environmental Protection Agency (2002).

The samples were collected from the first unconfined aquifer in the study area by shallow hand pumps and open wells falling. The locations of these wells were chosen to be near the agriculture areas. This method is applicable on pumping wells only with no need for observation wells; however, some of observation wells were far away from the pumping well, this observation wells usually used to observe fluctuation of ground water levels. The water samples were collected immediately after purging. All information concerning the samples was noted on the well sampling forms. All sample bottles were filled completely but (not allowed to overflow), capped, labeled, and the sealed sample containers were put into containers packed with ice and transported to analytical laboratory. Proper preservation, wherever needed, was done to ensure that the water quality of the sample did not change between the time of its collection (in the field) and the time of analysis in the laboratory. The top of the aquifer is expected to be the first to get affected, for any surface pollution, and therefore, is necessary to study its efficiency for groundwater pollution (Hussain et al. 2012). For different water quality indices, various variables may be selected according to the importance of the parameters and availability of data. In this study, we selected parameters according to availability of data and the 
desired criteria pollutants. Physical parameters such as total dissolved solids TDS, electrical conductivity EC, sodium $\mathrm{Na}$, potassium $\mathrm{K}$, iron $\mathrm{Fe}$, cadmium $\mathrm{Cd}$, lead $\mathrm{Pb}$, chromium $\mathrm{Cr}$, and nickel $\mathrm{Ni}$ ) are selected to be involved in the index. The strategy of this study includes classifying these parameters into five groups based on the human health importance of these parameters and negative effect of them on plants (Table 1).

The first group is relatively considered the most important one and involved two heavy metals $(\mathrm{Pb}, \mathrm{Cd})$, which has been identified as a higher risk to human health (Patrick and Chioma 2017). Whereas the last group includes the least important $(\mathrm{K}, \mathrm{Na})$ based on available reports and references (Hussain et al. 2012; Saeedi et al. 2009). TDS and $\mathrm{EC}$ were measured in the field by a conductivity meter. In the measurement of cations, $\mathrm{Na}^{+}$and $\mathrm{K}^{+}$were scaled using method 3500-K B, "flame photometric method" while method $3030 \mathrm{E}$, "acid digestion and analysis by flame atomic absorption spectrometry" was used for heavy metals analysis; The constituents selected analytical and procedures followed have been described in "standard methods for examination of water and waste water" (APHA, AWWA and WEF 1998). Summary of the physiochemical measurement of the groundwater samples presented in Table 2. Nine water quality parameters were selected to be included in the WQI. Even though many other water quality parameters aren't included in the index, a water index based on some very important parameters can provide a simple indicator of water quality. The index presented here is not specifically aimed at human health or aquatic life regulations, it gives the public a general idea of the possible problems with the water in the region.

\section{Transformation of raw data into rating values $(Y)$}

To relate data to global norms, each value of a field data parameter $\left(P_{i j}\right)$ is related to its desired standard value $\left(P_{\mathrm{id}}\right)$ as mentioned in (Hussain et al. 2012; Melloul and Collin 1998; Fipps 1996, Malik et al. 2014). The expected frequency $\left(X_{i j}\right)$ can be calculated by dividing these values and can be estimated as:

Table 1 Classification of water quality parameters on the basis of human health significance and negative effect on plants

\begin{tabular}{|c|c|c|c|}
\hline Parameters & Group & $\begin{array}{l}\text { Irrigation } \\
\text { standard (Fipps } \\
1996)\end{array}$ & Water quality criteria \\
\hline $\mathrm{Cd}$ & 1 & $0.01 \mathrm{ppm}$ & $\begin{array}{l}\text { Strongly poisonous to the metabolic activities (Sethy and Ghosh 2013) } \\
\text { Biologically, Cd is a nonessential, non beneficial element recognized to be of high toxic potential } \\
\text { It is deposited and accumulated in various body tissues } \\
\text { Toxic to human when ingested or inhaled. It is stored largely in the kidneys and liver and is excreted at an } \\
\text { extremely slow rate (Hussain et al. 2012) } \\
\text { Cause injury in any metabolism process such as seed germination and plant development. The redox } \\
\text { metal can generate oxidative damages (Janadeleh et al. 2015) }\end{array}$ \\
\hline $\mathrm{Pb}$ & & $5.00 \mathrm{ppm}$ & $\begin{array}{l}\text { It is a toxic metal that tends to accumulate in the tissues of human } \\
\text { may accumulate in plant tissues and prejudice food security (Iwuanyanwu and Chioma 2017) } \\
\text { It can inhibit plant cell growth at very high concentrations (Fipps 1996) } \\
\text { Cause losses in crop production and risks for human health. }\end{array}$ \\
\hline $\mathrm{Cr}$ & II & $0.10 \mathrm{ppm}$ & $\begin{array}{l}\text { The major effects of } \mathrm{Cr} \text { on seeds are manifested by overall abnormalities and decrease in germination, } \\
\text { reduced root and shoot elongation (Iwuanyanwu and Chioma 2017) }\end{array}$ \\
\hline $\mathrm{Ni}$ & & $0.20 \mathrm{ppm}$ & It is potential to become toxic in bioavailable forms at excessive levels (Sethy and Ghosh 2013) \\
\hline $\mathrm{Fe}$ & III & $5.00 \mathrm{ppm}$ & $\begin{array}{l}\text { Not toxic to plants in aerated soils, but can contribute to soil acidification and loss of essential phospho- } \\
\text { rus The use for long time of irrigation water with high Fe values can be reduced of production quality } \\
\text { due to its deposition on leaf and/or fruit (Hussain 2004) }\end{array}$ \\
\hline TDS & IV & 1500 ppm & $\begin{array}{l}\text { These is not generally considered a primary pollutant (e.g., it is not deemed to be associated with health } \\
\text { effects) - referred to as specific conductance (EC) or salinity }\end{array}$ \\
\hline $\mathrm{EC}$ & & $2000 \mu \mathrm{s} / \mathrm{cm}$ & $\begin{array}{l}\text { High EC water is not a common problem. However, high EC may occur in water from containment ponds } \\
\text { rich in fertilizer residues, certain wastewaters used for irrigation }\end{array}$ \\
\hline $\mathrm{Na}$ & $\mathrm{V}$ & $200 \mathrm{ppm}$ & $\begin{array}{l}\text { High sodium acts to inhibit plant uptake of calcium and magnesium from the media. Higher levels of } \mathrm{Na} \\
\text { may be tolerated depending on crop sensitivity, may contribute to raising the soluble salts (EC) level of } \\
\text { the growing medium or may inhibit water uptake by plants. Plant problems include injury from excess } \\
\text { soluble salts, growth reduction, and increased susceptibility to disease (Centre of agriculture, food and } \\
\text { environment) }\end{array}$ \\
\hline $\mathrm{K}$ & & $50 \mathrm{ppm}$ & $\begin{array}{l}\text { There are no direct effects on the human health. These plant nutrients generally occur in water at very low } \\
\text { levels. Presence in irrigation water at levels higher than a few parts per million may indicate the pres- } \\
\text { ence of pollution from fertilizers or other contaminants (Centre of agriculture, food and environment) }\end{array}$ \\
\hline
\end{tabular}


Table 2 Chemical measurement for nine parameters of groundwater samples

\begin{tabular}{llllllllllll}
\hline Code & Longitude & Latitude & $\begin{array}{l}\mathrm{Cd} \\
\mathrm{ppm}\end{array}$ & $\begin{array}{l}\mathrm{Pb} \\
\mathrm{ppm}\end{array}$ & $\begin{array}{l}\mathrm{Cr} \\
\mathrm{ppm}\end{array}$ & $\begin{array}{l}\mathrm{Ni} \\
\mathrm{ppm}\end{array}$ & $\begin{array}{l}\mathrm{Fe} \\
\mathrm{ppm}\end{array}$ & $\begin{array}{l}\mathrm{TDS} \\
\mathrm{ppm}\end{array}$ & $\begin{array}{l}\mathrm{Na} \\
\mathrm{ppm}\end{array}$ & $\begin{array}{l}\mathrm{K} \\
\mathrm{ppm}\end{array}$ & $\begin{array}{l}\mathrm{EC} \\
\mu \mathrm{s} / \mathrm{cm}\end{array}$ \\
\hline S01 & 44.39000 & 32.02611 & 0.09 & 0.43 & 0.03 & 0.09 & 1.16 & 2400 & 523 & 212 & 4816 \\
S02 & 44.38500 & 32.02500 & 0.09 & 0.69 & 0.04 & 0.15 & 3.93 & 2116 & 379 & 159 & 4232 \\
S03 & 44.37990 & 32.02489 & 0.07 & 0.43 & 0.03 & 0.12 & 1.32 & 2522 & 523 & 283 & 5045 \\
S04 & 44.38000 & 32.02670 & 0.08 & 0.16 & 0.04 & 0.02 & 0.10 & 2270 & 423 & 147 & 4540 \\
S05 & 44.39609 & 32.02982 & 0.11 & 0.48 & 0.04 & 0.03 & 0.99 & 3630 & 869 & 408 & 7260 \\
S06 & 44.38916 & 32.02173 & 0.07 & 0.21 & 0.04 & 0.04 & 0.20 & 2750 & 656 & 272 & 5500 \\
S07 & 44.38360 & 32.01830 & 0.08 & 0.37 & 0.05 & 0.07 & 0.39 & 1864 & 281 & 82 & 3729 \\
S08 & 44.36750 & 32.04891 & 0.07 & 0.35 & 0.05 & 0.04 & 0.06 & 2038 & 405 & 45 & 4077 \\
S09 & 44.35687 & 32.04400 & 0.07 & 0.45 & 0.05 & 0.02 & 1.03 & 1948 & 421 & 135 & 3896 \\
S10 & 44.36657 & 32.06000 & 0.07 & 0.53 & 0.06 & 0.00 & 0.06 & 1242 & 411 & 109 & 2484 \\
S11 & 44.36750 & 32.04891 & 0.07 & 0.36 & 0.05 & 0.04 & 0.06 & 2042 & 410 & 50 & 4085 \\
S12 & 44.37990 & 32.02489 & 0.08 & 0.45 & 0.03 & 0.13 & 1.35 & 2550 & 535 & 289 & 5050 \\
\hline
\end{tabular}

The maximum well depth is $25 \mathrm{~m}$, while the maximum well depth to water in Dibdibba aquifer is $50 \mathrm{~m}$
$X_{i j}=P_{i j} / P_{\mathrm{id}}$

where the $P_{i j}$ is the parameter value, and $P_{\text {id }}$ is the standard value of each parameter.

The corresponding rating or the relative pollution level $Y_{i}$ can be estimated for any value of $X_{i}$ by the following equation:

$Y_{i}=-0.712 X_{i}^{2}+5.228 X_{i}+0.484$.

According to Melloul and Collin (1998), the matrix of pair-wise comparisons is constructed from $i \times j$ elements, where $i$ and $j$ are the number of criteria $(n)$.

The index value of $Y_{i}$ is taken in a scale range from 1 to 10 and it corresponds to $X_{i j}$, as follows:

- When the value of $X_{i j}$ is equal to $0 \cdot 1$, the corresponding $Y_{i}$ would be around 1; and the water quality is classified as "good".

- When $X_{i j}$ is equal to 1 (the raw value of the parameter $P_{i}$ is equal to its standard desired value $\left(P_{i j}=P_{\text {id }}\right)$, the corresponding $Y_{i}$ would be 5 ; and water quality will be "acceptable".

- If $X_{i j}$ is equal to or higher than 3.5 (standard desired value), the corresponding index value of $Y_{i}$ would be 10 and groundwater quality becomes "unacceptable".

After all pair-wise comparison, matrices are formed, each criterion (parameter) is assigned a weight $\left(w_{i}\right)$.

\section{Evaluating weight of criteria by AHP approach}

AHP approach through expert choice v.11 program was applied to evaluate the weight of criteria $\left(w_{i}\right)$. While the comparisons between each criterion are made using the measurement scale of Satty (Tiwari et al. (2014)) which gives numerical values between 1 and 9 depending on the relative importance of the criterion (Table 3 ).

The $w_{i}$ is given value within a range between 0 and 5 on the basis of the human health significance and negative effect on plants (Table 1). This procedure is known as a synthesis judgment. The weight is a numerical value given to the parameters to characterize its relative anticipated pollutant impact. Lower numerical values define lower pollution potential and vice versa. After assigning weight to each criterion, the eigenvalue is normalized to obtain the priority vector (pollution impact) or relative unit vector. The highest priority vector is given a weight 5 (due to the need of rescaling as per the 0-5 scale of WQI). Calculation of unit weight $\left(W_{\mathrm{n}}\right)$ for various water quality parameters is proportional to the maximum values for this corresponding parameter and weights of the other chemical parameters are deduced accordingly.

Table 3 Pair-wise comparison in AHP preference (Satty 1980)

\begin{tabular}{ll}
\hline Definition & $\begin{array}{l}\text { Intensity of } \\
\text { importance }\end{array}$ \\
\hline Equally important & 1 \\
Moderately more important & 3 \\
Strongly more important & 5 \\
Very strongly more important & 7 \\
Extremely more important & 9 \\
Intermediate values & $2,4,6,8$
\end{tabular}




\section{The formula of WQI}

The basic WQI formula is expressed as the summation of weights multiplied by respective ratings of various parameters $\mathrm{i}$ for each cell $\mathrm{j}$ as following equation:

$\mathrm{WQI}=C / n\left(\sum_{i=1}^{n}(\right.$ Wri.Yri $\left.)\right)$.

$C=\mathrm{a}$ constant, used to ensure the desired range of numbers (taken as 10), and it represents the highest extent of the variables, $(n)$ is the number of variables used).

$i=$ number of chemical parameters involved $(i=1, \ldots, n)$. This value is incorporated in the denominator to the average the data.

Wri is the relative value of $\left(W_{\mathrm{i}} / W_{\max }\right)$, where the $W_{\mathrm{i}}$ is a weight for any given parameter, and $W_{\max }$ represents the maximum possible weight (taken as 5).

Yri is the value of $Y_{i} / Y_{\max }$, where the $Y_{i}$ is the rating as related to $X_{i}$ (Eq. 2) and the $Y_{\max }$ is the maximum possible rating for any parameter $\left(Y_{\max }=10\right)$.

The rating factor $(Y)$ is an importing factor which is lead to calculate Yri that considered being the main key to calculate the final Index.

\section{Result and discussion}

The statistical analyses of these elements are presented in Table 4 . The analyses results of these elements (mean value per sampling point) were used as input data in ArcMap environment. The coordinates of sampling points were integrated with the data for the generation of spatial distribution maps. The present study used the inverse distance weighted (IDW) method for spatial interpolation of groundwater parameters. IDW determines cell values using a liner-weighted combination set of sample points. The weight assigned is a function of the distance of an input point from the output cell location. The greater the distance, the less influence the cell has on the output value. The analyzing based on elements concentration change in the groundwater from the low concentration to high concentration, where this indicates that the presence of contamination points in that region. While the spatial distribution of the concentration of physico-chemical elements EC, TDS, $\mathrm{Na}, \mathrm{k}, \mathrm{Pb}, \mathrm{Cd}, \mathrm{Fe}, \mathrm{Cr}$ and $\mathrm{Ni}$ is shown in Fig. 2a-i, respectively.

\section{Calculation of the parameter weights}

As per the relative importance scheme in the AHP, the criteria of the parameters are transferred as input values for the AHP matrix in Excel Software. The unit weights assigned to each parameter used for calculating the WQI is given in the Table 5. Estimation of 'unit weight' assigned to each parameter considered in the calculation. By assigning unitweights, all the concerned parameters of different units and dimensions are transformed to a common scale. WQI compared to simply using the water quality standard, basically, is a numeric expression used to convey information on the quality of given water wells in such a way that it easily understood by dissension maker. The index is a dimensionless scale which aggregates several water quality parameters into a single value to make it understandable to the public in terms of its suitability to use (Patrick and William 2013; Tyagi et al. 2013). The Quality of groundwater can be variable depending on weight value calculated by AHP. In this study the WQI is developed by assigning relative weights to each parameter ranging from 1 to 5 based on the adverse effect of the water quality parameter on human health that associated with effect of concentration of these parameters on growth of plants or render the crop unfit for human consumption. As shown in Table 5, the maximum weight of (5) was assigned to both $\mathrm{Pb}$ and $\mathrm{Cd}$ on the basis of the higher effect elements (Table 1), on the other hand, the parameters such as TDS, K and Na had a minimum impact on the WQI and low weight value due to it is not deemed to be associated with health effects (even it has value above the irrigation standards).

Therefore, it is imperative to specifically consider relevant parameters and standards depending upon the application involved to develop an effective WQI.

\section{Calculation of the final WQI}

The final value of the index is computed according to Eq. 3 as follows:

The $\left(X_{i}\right)$ values are calculated for each parameter based upon Eq. (1), which represents an important factor for
Table 4 Statistical analyses for nine parameters of groundwater samples

\begin{tabular}{llllllllll}
\hline Code & $\begin{array}{l}\mathrm{Cd} \\
\mathrm{ppm}\end{array}$ & $\begin{array}{l}\mathrm{Pb} \\
\mathrm{ppm}\end{array}$ & $\begin{array}{l}\mathrm{Cr} \\
\mathrm{ppm}\end{array}$ & $\begin{array}{l}\mathrm{Ni} \\
\mathrm{ppm}\end{array}$ & $\begin{array}{l}\mathrm{Fe} \\
\mathrm{ppm}\end{array}$ & $\begin{array}{l}\mathrm{TDS} \\
\mathrm{ppm}\end{array}$ & $\begin{array}{l}\mathrm{Na} \\
\mathrm{ppm}\end{array}$ & $\begin{array}{l}\mathrm{K} \\
\mathrm{ppm}\end{array}$ & $\begin{array}{l}\mathrm{EC} \\
\mu \mathrm{s} / \mathrm{cm}\end{array}$ \\
\hline Minimum & 0.07 & 0.16 & 0.03 & 0.002 & 0.06 & 1242 & 281 & 45 & 2484 \\
Maximum & 0.11 & 0.69 & 0.06 & 0.15 & 3.93 & 3630 & 869 & 408 & 7260 \\
Average & 0.08 & 0.41 & 0.04 & 0.06 & 0.89 & 2281 & 486 & 183 & 4560 \\
SD & 0.01 & 0.14 & 0.01 & 0.05 & 1.09 & 579 & 154 & 112 & 1157 \\
\hline
\end{tabular}



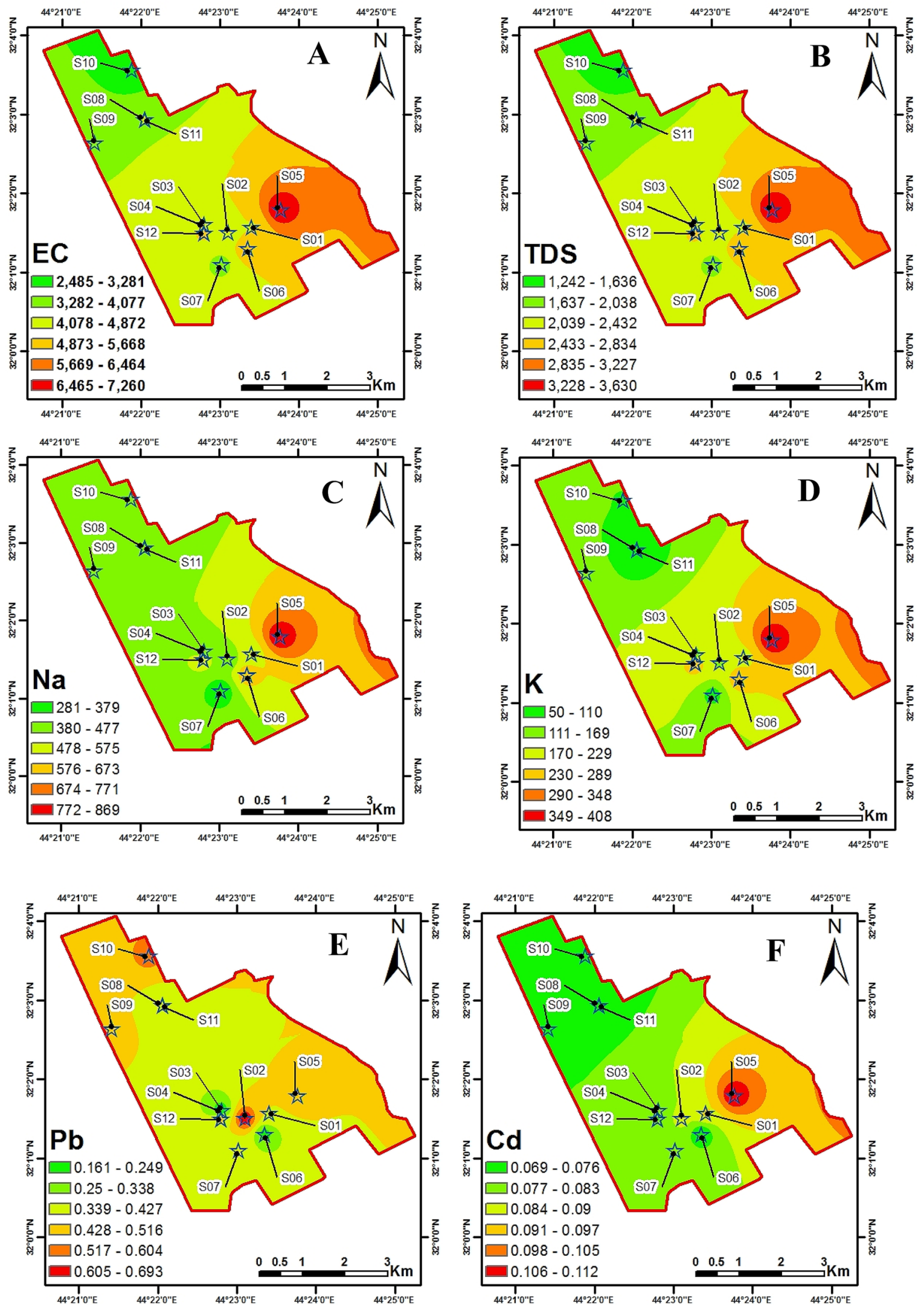

Fig. 2 Spatial distribution for concentration of (a) EC, (b) TDS, (c) $\mathrm{Na}$, (d) $\mathrm{K}$, (e) $\mathrm{Pb}$, (f) $\mathrm{Cd}$, (g) $\mathrm{Fe}$, (h) $\mathrm{Cr}$, and (i) $\mathrm{Ni}$ for the study area 

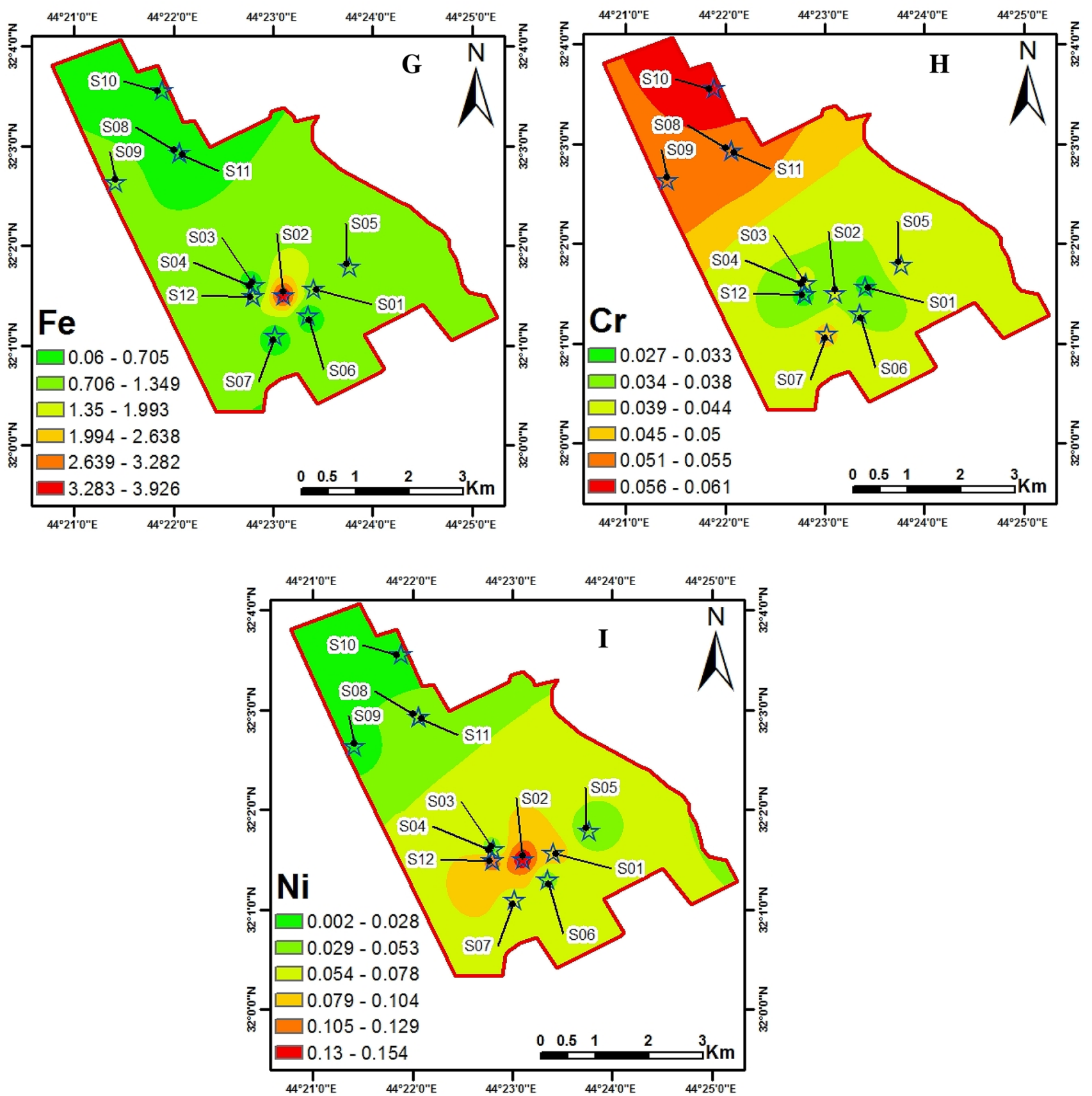

Fig. 2 (continued)

corresponding rate or the relative pollution level $Y_{i}$. Using Eq. (2), the $\left(Y_{i}\right)$ values are calculated.

The weight values $W_{i}$ for each parameter are prepared based upon AHP, subsequently the Wri values are calculated by dividing the $W_{i}$ value by $\left(W_{\max }=5\right)$. Whereas the values arrive at after summation of the nine values (Yri $\times$ Wri) using Eq. (3), they are multiplied by the value of $(C / N)$ which is $1.11(C=10, N=9)$. Where $C$ is constant and equal to 10 due to the $Y_{i}$ values that are ranging from 1 to 10 and
$N$ refers to the element's number which is 9 . Table 6 shows the final index for WQI for irrigation purpose. The groundwater classes and the range of index values according to five values of $Y_{i}$ exhibited in Table 7. These classes are relatively as comparably for one sample to others in study area and for all samples with irrigation standards. Because the standards enter in calculated of $X_{i}$ values which in turn enter in calculated of $Y_{i}$ which leads to calculated Yri and then in calculating of index consequently. The current index classifies 
Table 5 Pair-wise comparison matrix and weights of parameters base of Satty (1980) eigenvector procedure using expert choice program

\begin{tabular}{|c|c|c|c|c|c|c|c|c|c|c|c|c|}
\hline & $\mathrm{Pb}$ & $\mathrm{Cd}$ & $\mathrm{Cr}$ & $\mathrm{Ni}$ & $\mathrm{Fe}$ & TDS & $\mathrm{EC}$ & $\mathrm{Na}$ & $\mathrm{K}$ & Eigenvalue (E.V) & $\begin{array}{l}\text { Priority vector or nor- } \\
\text { malize E.V (E.V/3.9) }\end{array}$ & $\begin{array}{l}\text { weight } \\
\left(W_{i}\right) \text { if } \\
(0.254=5)\end{array}$ \\
\hline $\mathrm{Pb}$ & 1 & 1 & 2 & 2 & 7 & 8 & 8 & 9 & 9 & 1 & 0.254 & 5 \\
\hline $\mathrm{Cd}$ & & 1 & 2 & 2 & 7 & 8 & 8 & 9 & 9 & 1 & 0.254 & 5 \\
\hline $\mathrm{Cr}$ & & & 1 & 1 & 6 & 7 & 7 & 8 & 8 & 0.68 & 0.174 & 3.41 \\
\hline $\mathrm{Ni}$ & & & & 1 & 6 & 7 & 7 & 8 & 8 & 0.68 & 0.174 & 3.41 \\
\hline $\mathrm{Fe}$ & & & & & 1 & 2 & 2 & 3 & 3 & 0.176 & 0.045 & 0.88 \\
\hline TDS & & & & & & 1 & 1 & 2 & 2 & 0.117 & 0.030 & 0.5 \\
\hline $\mathrm{EC}$ & & & & & & & 1 & 2 & 2 & 0.117 & 0.030 & 0.5 \\
\hline $\mathrm{Na}$ & & & & & & & & 1 & 1 & 0.078 & 0.020 & 0.39 \\
\hline K & & & & & & & & & 1 & 0.078 & 0.020 & 0.39 \\
\hline sum & & & & & & & & & & 3.9 & 1 & \\
\hline
\end{tabular}

With accessible of inconsistency of 0.02 which must be less than $(0.1)$

Table 6 Calculation result of WQI for agriculture purpose and water type for wells samples

\begin{tabular}{llll}
\hline Well no & Sum $(\text { Wri } \times \text { Yri })^{\text {a }}$ & $\begin{array}{l}\text { WQI as in } \\
\text { Eq. (3) }\end{array}$ & Water type \\
\hline S01 & 1.75 & 1.95 & Permissible \\
S02 & 1.92 & 2.14 & Permissible \\
S03 & 1.79 & 1.99 & Permissible \\
S04 & 1.62 & 1.80 & Permissible \\
S05 & 1.74 & 1.90 & Permissible \\
S06 & 1.68 & 1.86 & Permissible \\
S07 & 1.69 & 1.87 & Permissible \\
S08 & 1.65 & 1.83 & Permissible \\
S09 & 1.68 & 1.87 & Permissible \\
S10 & 1.62 & 1.80 & Permissible \\
S11 & 1.65 & 1.84 & Permissible \\
S12 & 1.80 & 2.01 & Permissible \\
\hline
\end{tabular}

${ }^{a}$ Yri= rating or the relative pollution level, $\mathrm{Wri}=$ is the relative weight, where the $W_{i}$ is a weight for any given parameter

the samples according to range scale $0.43-4.33$ (Table 7), and the value of 2.16 reflected the limit between unpolluted and polluted groundwater. The classification values of WQIs resulted in this study are similar to several other models which determined to assess the surface and ground water vulnerability for pollution (Table 7). The applicable model for this table would support and validate the present results.

The range value of WQI in Tables 7, 8 was imported for ArcView for processing to prepare the final WQI maps which are shown (Fig. 3). The result from this research refers, that the WQI can be variable depending on the purpose for which the variables are used. Researchers have been conducted throughout the world to determine the effects of toxic heavy metals on plants (Sethy and Ghosh 2013; Janadeleh et al. 2015; Alves et al. 2016) for example,
Sethy and Ghosh (2013) stated that heavy metals including $\mathrm{Cd}, \mathrm{Pb}, \mathrm{Ni}$, and $\mathrm{Cr}$ are important environmental pollutants that cause toxic effects to plants; thus, lessening productivity and posing dangerous threats to the agro-ecosystems. They act as stress to plants and affect the plant physiology (Sethy and Ghosh 2013). Moreover, exposure to heavy metals, such as $(\mathrm{Cd}),(\mathrm{Pb})$, has been identified as a risk to human health through consumption of vegetable crops (Iwuanyanwu and Chioma 2017; Hussain 2004, Centre of agriculture, food and environment 2020). Harmful effects on plant or general human health were used as key significance of these parameters in water quality assessment and their considerable impact on the index.

Therefore, the sensitivity function 5 denotes a parameter that is most significant for human health and negative effect on agriculture (e.g., $\mathrm{Pb}, \mathrm{Cd}$ ). On the other hand, the function 1 corresponds to a parameter that has a minimal impact or less toxic (e.g., Na, K) (Centre of agriculture, food and environment 2020). The result found that a groundwater was adequate for irrigation purpose even with high concentration of TDS, Na and EC.

It can be noticed from comparing the (WQI) detected in Table 8, with the relative pollution level or rating values $Y_{i}$ in Table 1 and also in comparison with irrigation water quality standards in Table 1 , that all groundwater samples over study area are suitable for agriculture. As consequences, most of the index factors of $X_{i j}$ produce values $<3.5$ times standard desired value), which means that the corresponding value of $Y_{i}$ is $<310$, which indicates an acceptable value for irrigation purpose and unpolluted groundwater in the study area. The current index makes the results more rapid and simpler rather than a long list of numerical values for a large variety of parameters, and it assists in the comparison between various sampling sites and/or events. 
Table 7 Illustrate several WQIs classification comparing with currently study index

\begin{tabular}{|c|c|c|c|c|c|}
\hline WQI range & Classification or index type & Samples no & Categories & Parameters & Reference \\
\hline $0-4.33$ & Mellol and Collin (1998) & 12 & $\begin{array}{l}\text { Very good:0-0.43 } \\
\text { Good: } 0.43-1.08 \\
\text { Permissible: } 1.08-2.16 \\
\text { Polluted: } 2.16-3.25 \\
\text { V.Polluted: } 3.25-4.33\end{array}$ & $\begin{array}{l}\mathrm{Pb}, \mathrm{Cd}, \mathrm{Cr}, \mathrm{Ni}, \mathrm{Fe}, \mathrm{TDS}, \mathrm{EC}, \mathrm{Na} \text {, } \\
\mathrm{K}\end{array}$ & Current study \\
\hline $0-4.1$ & Don (1995) and Todd (2007) & 33 & $\begin{array}{l}\text { Excellent: } 0-04 \\
\text { Good: } 0.4-1.04 \\
\text { Permissible: } 1.04-2.08 \\
\text { Poor: } 2.08-4.1\end{array}$ & $\begin{array}{l}\text { TDS, } \mathrm{pH}, \mathrm{Ec}, \mathrm{SO}_{4}, \mathrm{Ca}, \mathrm{Mg}, \mathrm{Na}, \mathrm{K} \\
\text { Cl. AR, } \mathrm{Na} \% \text { and T.H }\end{array}$ & Hussain et al. (2012) \\
\hline $0-3.5$ & Mellol and Collin (1998) & 8 & $\begin{array}{l}\text { Lowest pollution: } 0 \\
\text { Maximum pollution: } 3.5\end{array}$ & $\begin{array}{l}\mathrm{Cd}, \mathrm{Mn}, \mathrm{Pb}, \mathrm{Fe}, \mathrm{NO}_{3} \text {, alkalinity, } \\
\text { TDS, } \mathrm{Ca}\end{array}$ & Hussain et al. (2012) \\
\hline $0-100$ & Meireles et al. (2010) & 36 & $\begin{array}{l}85 \leq 100: \text { No restriction } \\
70 \leq 85: \text { Low restriction } \\
55 \leq 70: \text { Moderate } \\
40 \leq 55: \text { High restriction } \\
0 \leq 40: \text { Severe restriction }\end{array}$ & $\mathrm{EC}, \mathrm{Na}, \mathrm{Cl}, \mathrm{HCO}_{3}, \mathrm{SAR}$ & Hussain et al. (2014) \\
\hline $0-100$ & Harkins (1974) and Ott (1978) & 7 & $\begin{array}{l}\text { Excellent:0-25 } \\
\text { Good: } 26-50 \\
\text { Poor: } 51-75 \\
\text { Very poor: } 76-100 \\
\text { Unsuit-able: }>100\end{array}$ & $\begin{array}{l}\text { pH, Alkalinity, Turbidity, TDS, } \\
\text { Hardness, } \mathrm{Ca}, \mathrm{Mg}, \mathrm{Cl}, \mathrm{SO}_{4}, \\
\text { NH3, F, Fe, Al }\end{array}$ & Alobaidy et al. (2010) \\
\hline
\end{tabular}

Table 8 The groundwater classes base on the range of $Y_{\mathrm{i}}$ values

\begin{tabular}{lll}
\hline$Y_{i}$ & WQI value & Groundwater class \\
\hline 1 & $0.43(0-0.43)$ & Very good \\
2.5 & $1.08(0.43-1.08)$ & Good \\
5 & $2.16(1.08-2.16)$ & Permissible \\
7.5 & $3.25(2.16-3.25)$ & Polluted \\
10 & $\geq 4.33(3.25-4.33)$ & Very polluted \\
\hline
\end{tabular}

The numbers between the parentheses mean the limitations for groundwater classes

\section{Application of the final WQI map using GIS}

The final WQI values are exported to Arc Map of GIS software in order to prepare the final WQI maps of study area shown in Fig. 3. The GIS technique uses spatial analyst extension in ArcMap to prepare the maps to predict the spatial distribution of final index values for groundwater quality for irrigation purpose. The map shows that the groundwater is deteriorating along the south and southwest region with the incorporation of the pollutants discharged from urbanized/industrial/agricultural west, and it increases the WQI index. This study finds out that the WQI index together with GIS can help the decision makers in the assessment and management of groundwater, and it can be considered as useful tools to choose less polluted areas for wells drilling.

The GIS-based WQI and thematic maps discussed earlier could be used to prevent (1) soil and water deterioration. (2)

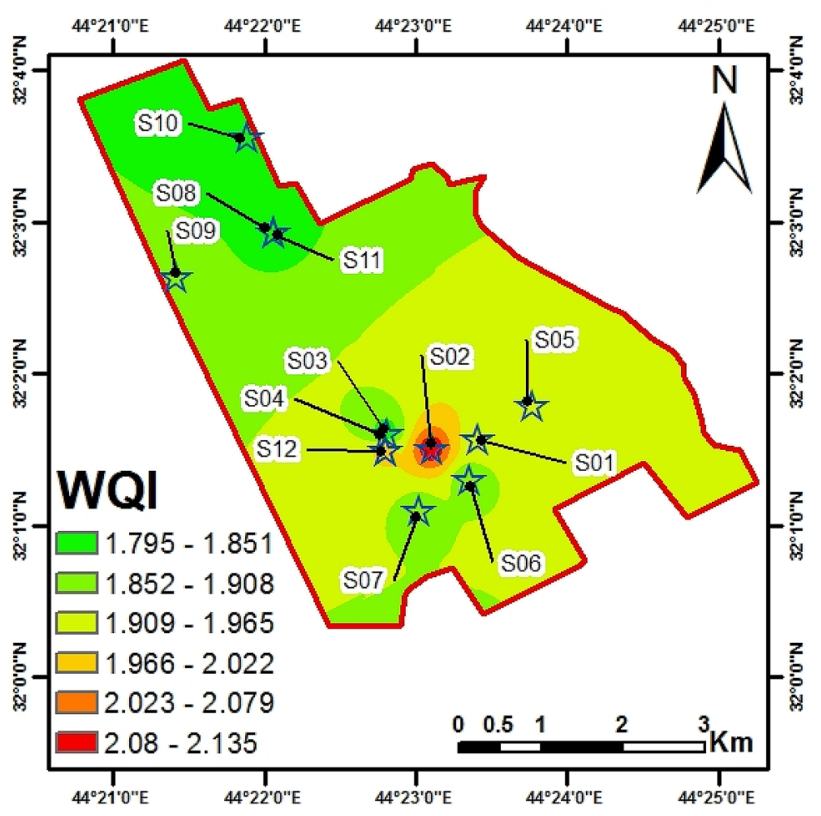

Fig. 3 Spatial distribution of the final WQI for the study area

Vital problems in agricultural production. Therefore, it could help the sustainable management of natural resources in the study area, also for all area of the Dibdibba aquifer. 


\section{Conclusions}

This study, the WQI is modified to assess the groundwater for irrigation purposes, as a case study at an agricultural area; near Al Kufa city, North of Al Najaf province, Iraq. To achieve this aim, nine parameters are included: TDS, $\mathrm{EC}, \mathrm{Na}^{+}, \mathrm{K}^{+}, \mathrm{Cd}, \mathrm{Fe}, \mathrm{Ni}, \mathrm{Pb}$ and $\mathrm{Cr}$. To calculate the final WQI, all of the normalized parameters are combined. Also, the relative importance or the weights of the parameters in the final index are defined. The result indicates that the index recorded values are between 0 and 4.33 or more, and the value of 2.16 represents the limit between unpolluted and polluted groundwater. To conclude, the index map shows that groundwater in the studied area is good and the quality water type is acceptable for irrigation purposes. Finally, the WQI modeling can be used as a tool to map the groundwater quality considering the weights of an ensemble of chemical parameters together to decipher the area affected by pollution. The results revealed that the water in all the reservoirs is suitable for irrigation with no hazard to the soil structure. The WQI and GIS showed a great potential in the assessment of water for multi-purpose usage. These are excellent tools for summarizing overall water quality conditions over space and time. When used together, they are also a method of providing relevant information for specific water use that can be more readable for planners and managers.

Acknowledgements Open Access funding provided by Lulea University of Technology.

Open Access This article is licensed under a Creative Commons Attribution 4.0 International License, which permits use, sharing, adaptation, distribution and reproduction in any medium or format, as long as you give appropriate credit to the original author(s) and the source, provide a link to the Creative Commons licence, and indicate if changes were made. The images or other third party material in this article are included in the article's Creative Commons licence, unless indicated otherwise in a credit line to the material. If material is not included in the article's Creative Commons licence and your intended use is not permitted by statutory regulation or exceeds the permitted use, you will need to obtain permission directly from the copyright holder. To view a copy of this licence, visit http://creativecommons.org/licenses/by/4.0/.

\section{References}

Al Azawi, Ali A (2009) Evaluation and management of groundwater in Bahr Al Najaf Basin, Ms.c thesis, university of Baghdad, Collage of Science

Al-Ansari NA (2013) Management of water resources in Iraq: perspectives and prognoses. J Eng 58:667-684

Al-Kubaisi QY, Al-Abadi AM, Al-Ghanimy MA (2018) Mapping groundwater quality Index for irrigation in the Dibdibba aquifer at Karbala-Najaf plateau, central of Iraq". Iraq J Sci 59(3C):1636-1652
Alobaidy AM, Maulood BK, Kadhem AJ (2010) Evaluating raw and treated water quality of Tigris river within Baghdad by index analysis. J Water Resour Protect 2:629-635

Alves L, Reis A, Gratão P (2016) Heavy metals in agricultural soils: from plants to our daily life. Jaboticabal 44(3):346-361

APHA, AWWA, WEF (1998) Standard methods for examination of water and wastewater, 20th edn. Washington

Brown RM, McClelland NI, Deininger RA, Tozer RG (1970) A water quality index-do we dare? Water Sewage Works 117(10):339-343

Bouderbala A (2017) Assessment of water quality index for the groundwater in the upper Cheliff plain, Algeria. J Geol Soc India 90:347. https://doi.org/10.1007/s12594-017-0723-7

Centre of agriculture, food and environment. Water quality for crop production. Retrieved from: https://ag.umass.edu/greenhouse -floriculture/greenhouse-best-management-practices-bmpmanual/water-quality-for-crop

Don CM (1995) A grows guide to water quality. University college station, Texas

Gautam SK, Sharma D, Tripathi JK, Ahirwar S, Singh SK (2013) A study of the effectiveness of sewage treatment plants in Delhi region. Appl Water Sci 3(1):57-65

Fipps G (1996) Irrigation water quality standards and salinity management strategy, Texas Agricultural Extension Service, Texas A\&M University System

Harkins DR (1974) An objective water quality index. J Water Pollut Control Fed 46:588-591

Hussain HM (2004) Assessment of ground water vulnerability in an alluvial interfluve using GIS. Unpublished Ph.D Thesis, Department of Hydrology, Indian Institute of Technology Roorkee, Roorkee-247 667 (India)

Hussain HM, Al-Hasnawi S, Al-Shammaa A (2012) Assessment of index for aquifer water quality for irrigation and livestock purposes of Dammam Aquifer in Najaf area of Iraq. J Karbala $1(1): 22-32$

Hussain HM, Al-Haidarey M, Al-Ansari N, Knutsson S (2014) Evaluation and mapping groundwater suitability for irrigation using GIS in Najaf Governorate, Iraq. J Environ Hydrol 22:1-16

Iwuanyanwu KP, Chioma NC (2017) Evaluation of heavy metals content and human health risk assessment via consumption of vegetables from selected markets in Bayelsa State Nigeria. Biochem Anal Biochem 6:332. https://doi.org/10.4172/21611009.1000332

Janadeleh H, Kardani M, Salemi M (2015) Study of heavy metals effects on plants. In: Third International Symposium On Environmental and Water Resources, Engineering, 2-3 June 2015, Tehran, Iran

Malik D, Singh S, Thakur J, Singh RK (2014) Heavy metal pollution of the Yamuna River: an itrospection. Int J Curr Microbiol App Sci 3(10):856-863

McClelland NI (1974)Water quality index application in the Kansas River Basin, EPA-907/9-74-001. US EPA Region VII. Kansas City, MO

Meireles ACM, Andrade EMD, Chaves LCG, Frischkorn H, Crisostomo LA (2010) A new proposal of the classification of irrigation water. Revista Ciência Agronômica 41(3):349-357

Melloul AJ, Collin M (1998) A proposed index for aquifer water quality assessment: the case of Isrels' Sharonregion. J Environ Manag 54:131-142

Orozco CDLM, Lopez HF, Arias HR, Duran AC, Rivero OJ (2017) Developing a water quality index (WQI) for an irrigation dam. Intern J Environ Res Public Health 14(5):439. https://doi. org/10.3390/ijerph14050439

Ott WR (1978) Environmental indices: theory and practice. U.S. Department of Energy, Washington, DC, USA 
Patrick JW, William JW (2013) Water Quality Index Aggregation and Cost Benefit Analysis. Journal of Benefit-Cost Analysis 4(1):81-105

Patrick KI, Chioma NC (2017) Evaluation of heavy metals content and human health risk assessment via consumption of vegetables from selected markets in Bayelsa State. Nigeria. Biochem Anal Biochem 6:3. https://doi.org/10.4172/2161-1009.1000332

Ramakrishnaiah CR, Sadashivaiah C, Ranganna G (2009) Assessment of water quality index for the groundwater in TumkurTaluk, Karnataka State, India. E-J Chem 6(2):523-530

Rawat KS, Tripathi VK, Singh SK (2017) Groundwater quality evaluation using numerical indices: a case study (Delhi, India). Sustain Water Resour Manag 4:875-885

Satty L (1980) The analytical hierarchy process: planning, priority setting, resource allocation. McGraw-Hill, New York

Saeedi M, Abessi O, Meraji S (2009) Development of groundwater quality index. Environ Monit Assess 163(1-4):327-335

Sethy SK, Ghosh S (2013) Effect of heavy metals on germination of seeds. Journal of Natural Science, Biology and Medicine 4(2):272-275
Tiwari AK, Singh PK, Mahato MK (2014) GIS-based evaluation of water quality index of groundwater resources in West Bokaro Coalfield. India Curr World Environ 9(3):843-850

Thakur JK, Diwakar J, Singh SK (2015) Hydrogeochemical evaluation of groundwater of Bhaktapur Municipality. Nepal Environmental Earth Sciences 74(6):4973-4988

Todd DK (2007) Groundwater hydrology, 2nd edn. Wiley, India, p 535

Tyagi S, Sharma B, Singh P, Dobhal R (2013) Water quality assessment in terms of water quality index. Am J Water Resour 1(3):34-38

U.S. Environmental Protection Agency (2002) Guidance on choosing a sampling design for environmental data collection, EPA QA/G-5S, Office of Environmental information, Washington, DC 20460

Publisher's Note Springer Nature remains neutral with regard to jurisdictional claims in published maps and institutional affiliations. 